\title{
春日社付属殿含の機能について (2)
}

正全員佐 藤 正 彦*

序：当報告は同表題の論：文・その 1 (本諭：第 228 号，昭和 50 年 2 月号) に 続くものである。

\section{3. 移殿の機能}

移殿は「遷殿」とも記され，仮殿の機 能を有する。仮殿は造替の時に，一時御 神体を納めておく仮の社殿である。春日 社の場合，本社 4 殿と摂社若宮社 1 殿の 計 5 棟の社殿が同時に造替される。この 時，各タの仮殿を独立して設けるのでは なく，移殿の一部分を整频し，そこに御 神体を仮遷座し仮殿としたのである。し たがって，移殿は仮殿設備を一部に有专 る殿舎で，創建当初は『貞観儀式』に記 す「神殿座」であった。

この「神殿座」に相当する建物が平安 末一一れは恐らく長治元年 (1104) の造替から 一 に仮㩔の設備をここ記けて以来「移殿」之称されるよ うになったらしい。しかし，仮殿設備がこの位置に設け られたのは長治元年 (1104) より早かったかも知れな い。それは，春日社の創建が奈良時代であるから，長治 時をでに何回か破損に店じて造替もしくは修理を繰り返 しているからである。このことは後の記録だが，『当社 造替年序記』によって明らかである。その時にむ仮殿は 必要だったものと思5。しかし，『中右記』長治元年 (1104) 4 月 22 日の条珐

此御社年来之間, 遷宮之儀不慥知給 と記す。そしてこれょり古い造替についての記録はみ つからない。したがって, 長治時以前に移殿に仮殿設供 を設けたのか，それとも別に仮殿をたてたの为，㐫いい 江仮殿を設けなかったのか，かがらない。かし，『貞観 儀式』に「神殿座」と記すことは，たとえ，図一18 に み觉るよらな仮殿設備ではなくても，当時の造替もしく

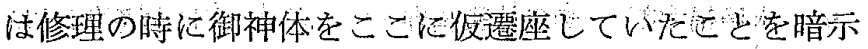
していないだろ.らか。

さて，移殿には本社および若宮社の造替の時に，必ず 仮殿設備が設けられ，御神体が仮遷座された。この時, 御神体ば办りでなく，ほ力の神宝類もここに納められた ので，移殿は宝蔵の機能も有している11。

移殿に收納された神宝類には 図一19 によれば，弓， 鐵、太刀などがあっだ。

移殿に神宝類が収納されるのは本社や若宮社の造替時 ばがりではない。常時神宝類を収納しておくく宝蔵の造替 むしくは修理の時にも宝蔵に收納されている神宝類をこ こに移してから，修理に着工しだ。

つぎに，移殿に設けられる仮殿設備がどのようなもの であり，移殿が仮遷宮や正遷宮の時にぼのように使用さ れるかといら問題があろら。まず，前者の仮殿設備の問 題比つ认ては特に 図一19によって, 後者の使用方法の 問題につでては 図一18 と図一20によって明らかであ

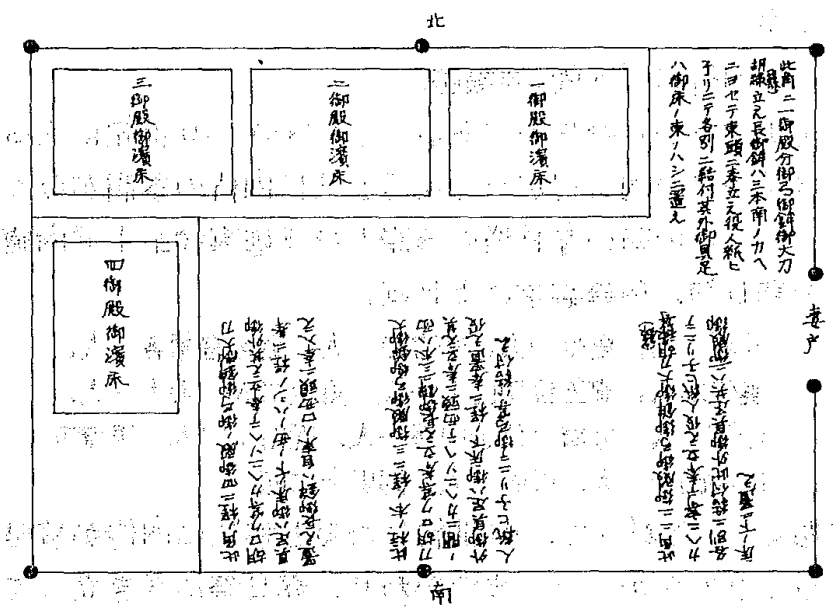

图-19 貞治 6 年 (1367) 移殷御神宝安置指図 (『春日社正下遷舜秘記』より転写) 


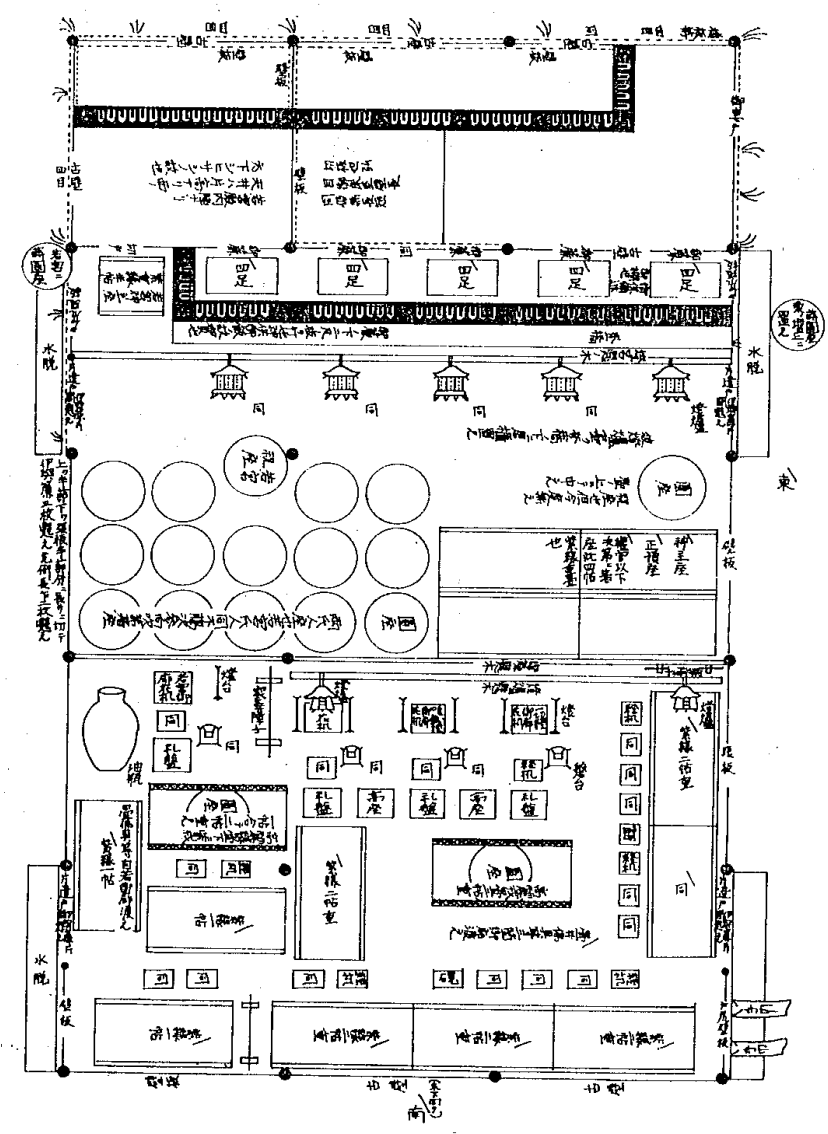

図一20『応永十四年春日社造替日記上』より転写

ろう。元来，この建物の佅はそれを明示する記録はない が，土間だったらしい。それが 図一18 のような仮殿設 備を設けるようになってから板敷に改められたようであ る。さらに，板敷の上に 図一20 にみられるように畳, 経机, 礼盤, 盤台などの調度が整えられた。そして, 遷 座式に参加する神主, 正預, 氏人, 権宮以下の人々の着 座の場所に使用された。移殿が人々の着座の場所となっ たのは遷座式以外にもあって，その一例として春日祭が ある。

令制時代すなわち 9 世紀末までは春日祭に内侍が加わ って参詣していた。そして内侍がこの移殿に着くので， 移殿を「内侍所」とも称しだ〉。それは『貞観儀式』春 日祭儀に

次内侍以下入就 $=$ 神殿座-

と記すことから明らかである。ところが，10 世紀に入る と令制時代の内侍司がなくなると共に内侍の参詣がなく なった。この頃の春日祭の参詣人は『延喜式』十五内蔵 寮の春日祭, 使等装束によれば,

外記一人，史生一人，辦官吏一人，史生官掌各一人， 㬇使二人，寮五位助已上一人，史生二人，舎人一人， 仕丁一人，近衛少将若中将一人，近衛十二人，馬寮五 位助已上一人，馬部一人，御馬十二匹

である。したがって，10世紀になると移殿に内侍が着座 することもなかった。そのかわり，春日祭にさき立って 来る祭使が移殿に入った ${ }^{5)}$ 。しかし, 春日祭の当日は移 殿は使用されなくなったらしい。ここで, 移殿の性格を
知るために記録を整理すると次のようになる。

\begin{tabular}{|l|l|l|l|}
\hline 員観儀式 & 延喜式 & 西宮記 & 江家次第 \\
\hline 神 股 座 & 記載なし & 内侍所 & 内侍 所 \\
\hline
\end{tabular}

上記により，内侍司が廃止された 10 世紀になっても なお内侍所と称していることに着目したい。そして，移 殿といら呼称はまだあらわれてこない。しかし，内侍所 が内侍司の廃止と共に春日祭にも使用されなくなると， この殿舎があっても何の意味もなくなる。このような状 態の時に, 図一18のような本格的な 仮殿設備をここに 設けるよらになったものと推測される。それが，さきに 述べた長治元年 (1104) 時の造替の時からであろうと思 われるのである。

つぎに，春日の神木のことに触れよう。

藤原氏の撜関政治の展開に伴って, 大和国の藤原氏知 行国化が進められた。このため春日社の大和国一宮化が みられる一方, 藤原氏の荘園も多くなった。同じく勢力 を維持するため, 茌園獲得を狙っている興福寺は藤原氏 にまねて春日社への接近をはかった。やがて, 院政期に なると，国司がこれら荘園に対し圧迫を加えた。このた め, 興福寺は春日社と一体となって神木をもって中央へ 強訴しだ。。これがかの有名な当社の神木動座入洛であ る。この時持参する神木はこの移殿に奉納されていたの である7。ちなみに, 神木動座入 洛の初見は宽治 7 年 (1093) である8。

移殿における管見に当たった（幕末までの資料）使わ れ方はおよそ以上であって，他に利用されていない。っ ぎに移殿の使われ方について要約しておく。

1）春日祭の時, 内侍の着座する所であった。

2）本殿造替の時，仮殿設備を設けた。なお，若宮社 が創建されてからは若宫社の仮殿設備もここに設け た。

3）遷座式の時, 関係者の着座の場所となった。

4）宝蔵の造り替えの時, 神宝類の置き場所とな。 た。

5）神木の置き場所でもある。

[注]

1)『中右記』長治元年 (1104) 4 月 22 日の条。

2) 『旧記勝出』大治 2 年 (1127) 4 月 5 日の条。

3) 『中臣祐定記』代治 2 年 (1241) 6 月 8 日の条。

4) 『西宮記』『江家次第』。

5）『西宮記』臨時十祭使事。

6）永島福太郎：春日社興福寺の一体化 (『日本歴史』 125 号)。

7）『中臣祐賢記』文永元年 (1264) 8 月 6 日の条。『細主要記 抜書』文和 5 年 (1356) 1 月 13 日の条。

8) 『百練抄』同年 8 月 26 日の条。『康富記』宝德 3 年 $(1451)$ 9 月1日の条には「神木入洛宽治七年初度也」とみ元る ので，筧治 7 年としたが，安和元年 (968) とする説もあ る。

4. 三御廊, 捻廊, 中門の機能

イ. 三御㵊と捻廊の機能 
春日祭の時, 晴天であれば，撆殿の北側の斎庭を通っ て石段を上り中門に来て社前にて参抨するが，雨天だと 斎庭を通って社前に来ることはできない。このような 時, 御廊は関係者の通路として使われる。すなわち, 春 日祭に関倸する人々は捻廊を上り，西御廊を経て中門に 来てはじめて参拝することになる1”。つまり，春日祭当 日, 雨天の場合には御廊南, 幣殿北の斎庭で行なわれる べき種々の儀式も行ならことが出来ず，幣殿などで行な らので，本殿に参择する順路も変わってくる。捻廊や西 御廊が雨天の日などに社前に来る時, どらしても通路と して使われることはその構成された位置からも当然であ ろ.5。．また，正遷宮の時に，舞楽が斎庭で行なわれる が, この時西御廊は斎庭で行なわれる舞楽の見物場所で もあった ${ }^{2)}$ 。例えば，元禄 2 年 (1689) 時の正遷宮のお 祝いの舞楽の時には一乗院御門跡が西御廊で舞楽を見学 している。また, 西御廊には南側に筫子縁があるが, こ こも寺僧達の見物席となっだ”。をして，捻廊も神事の 時に雨降りなどにぶつかると西御廊と同様に見物磨とし て使われることもあっだ。

それでは一体東御瑯はどのような機能を持つかつぎに みてみよう。

神事の時に度々舞楽が行なわれるが, 舞楽は普通, 斎

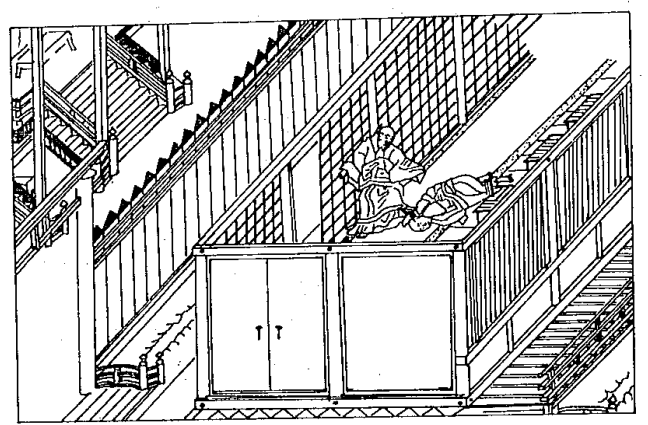

図一21『春日権現験記』より転写

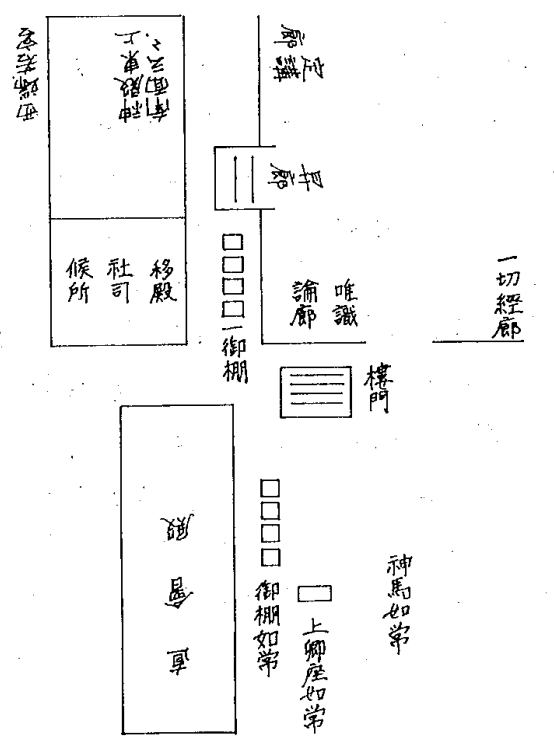

図一22『元長卿記』永正 5 年 (1508) 2 月 の条より転写
庭で行なわれる。舞殿は吹拔きで, 幕などを周囲に張り めぐらしても寒い日などは，舞人も見物人も共に困る。 このような時に，周囲に多少とも囲いのある東御廊で舞 が行なわれたことがある5。

その他，東御廊で修学僧が唯識論を読んだこともあ る。その時の様子は 図一21 で明らかであろう。この図 によれば，東御廊の床は畳敷きである。

春日社では唯識論の他に，一切経が読まれたり，長講 が行なわれたりするが，これらの仏事も御廊で行なわれ た。仏事関係の御廊の性格を示すものとして 図一22 が ある。この図によれば, 東御廊二一切経廊, 西御廊二唯 識諭廊, 北御廊二定講廊であるが，さきに述べたように 東御嫏で唯識論を読経することもあるので，必ずしもこ のよらな使われ方をしていなかったらしい。例えば，東 御廊を「一切経廊」と記すのは 図一22 の他に『中臣祐 春記』弘安 10 年 (1287) 10 月 11 日の条などであるが, 東御廊を「唯識論廊」゙)，もしくは「長講廊」と記すもの もある7゙。

また, 文永 10 年 (1273) に内大臣花山院師継が参詣し た時には例によってまず本社に参扯し，次に若宮社に参 扯して再び本社にもどるが，もどった時，幣殿の東側を 通って，楼門すなわち中門から東御廊に入り，ここで御 経の供養が行なわれた

その他, 東御廊は畳敷きで, 一応周囲が連子空や明障 子などで区切られているためか, 寺家が参詣して通夜な ぞにも使われだ”。

また，特殊な場合ではあるが，神宮寺を造替する時に 仮殿を東御榔に設けることもあった。神宮寺は東御廊の 南, 東回廊の西側に存在したが, これを造替する時は, 仮殿を通常東回廊に設ける。しかし，東回廊の造替もし くは修理とぶつかった場合にはやむを得ず，東御廊に仮 殿を設けたのである ${ }^{10)}$ 。仮殿は東御廊の東第 1 間（現在 ここの南面は両開きの板戸になっていて開放できる）に 設けられた。

つぎに，本社の造替の時に三御廊がどのように使われ たかみてみよう。

正遷宮の時, 舞は舞殿北の斎庭で行なわれるが, 音楽 を奏でる楽人達の座は東御廊に設けられる ${ }^{11}$ 。そして， さきに述べたよらに，西御廊が見物席として使われるこ ともあった。

以上のように，三御廊はその位置から他の神社（例え ば鶴岡，石清水など）に扔ける回廊的性格を有する。そ のために，回廊よりも早く創建されたのかも知れない。 ちなみに，揄廊は大治 2 年 (1127) k創建され，かつ 『中右記』寛治 7 年 (1093) 3 月 20 日の条に「社前南廊」 や「西廊」と記すので, 三御廊の創建は大治 2 年 (1127) を下らないものと思う。

最後に, 捻廊には, 参拝の時に 清める 手水桶, 手水 
布，构子などが置かれていたことをつけ加えておく ${ }^{12) 。 ~}$ 口. 中門の機能

中門の機能を知るためには，まず，つぎの三つの絵図 (図一23，24，25）をあげるこよができる。いずれの絵 図も延慶 2 年 (1309) に完成した『春日権現験記』の絵 図である。

図一23，24，25 をみると，中間にて何かが行なわれる 時には床に円い蓙（蔏）を敷いてそこに着座しているこ とが注目される。中門まで人々が入ってくると，立った ままの姿勢で参纬するのではなく，常に着座して参扯し たのである。着座する人は何も身分の高貴な人とは限ら ず，総ての人々がそうであったらしい。

着座する時に敷く蓆は史料では「楼門畺敷」などと記 すが13), 現在の畳とは違って, 図にみられる円い蒂だっ たのであろう。それは別の史料によれば「中門ニワラウ タヨ敷」とも記すからである位。

さて，文永 4 年 (1267) に回廊の造替が行なわれた

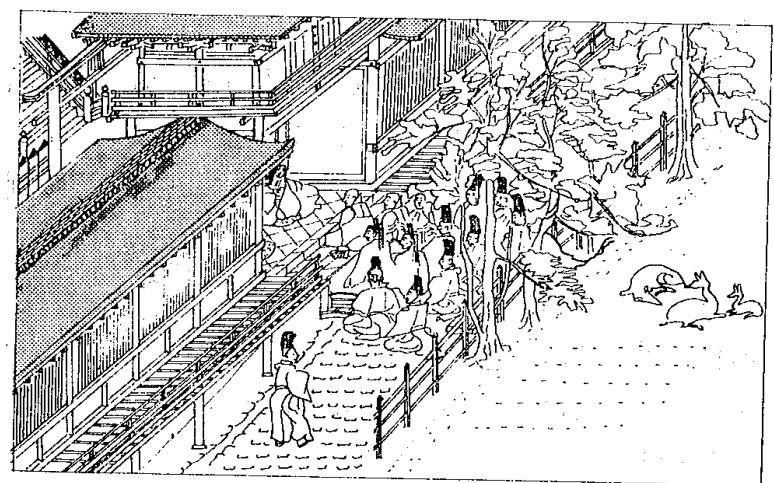

図一23『春日松現験記』より転写

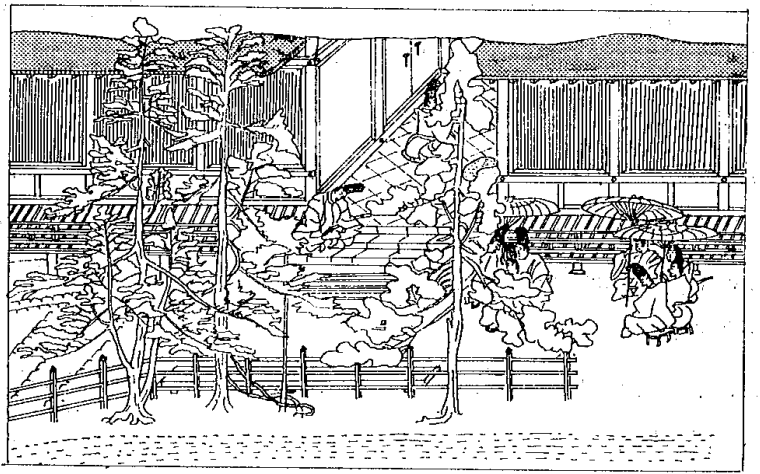

図一24『春日権現験記』より転写

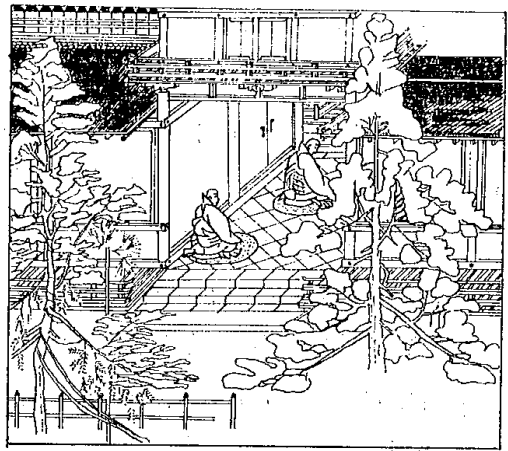

図一25 『春日権現験記』より転写
が，この釿始の式に，社司達が楼門の下に着座してい $る^{15)}$ 。この時の状態はまさに図一23 や図一24にみえ るように楼門 (中門) の外に着座したものであろう。

三御廊，捻廊，中門に扮ける管見に当たった（幕末ま での資料）使われ方はおよそ以上であって，他には利用 されていない。つぎに，三御廊，捻廊，中門の使われ方 を要約しておく。

1)、東御廊は唯識論や一切経などの読経を行なうとこ ろであると同時に，舞などの時楽人座として使う。 読経関係の調度がある。なお, 特別な場合として, 神宮寺の仮殿が設けられた。

2）西・北御廊は舞などの時，見物場所として使わ秃 た。なお，西御廊は捻廊と共に雨天に社前に参拝す る時, 通路となった。

3）中門は, 参洋，ある以は院宣，託宣など読み上げ る。この時, 円座 (橖座) を敷いて着座の姿㙯がと られた。

[注]

1)『中臣祐賢記』文永 9 年 (1272) 11 月6 日の条。

2) 『春日社御造営之記』元禄 2 年 (1689) 5 月 19 日の条。

3）『宽永年中御造替部』。

4) 『中臣祐春記』弘安 10 年 (1287) 6 月 23 日の条。

5) 『中臣祐定記』嘉禎 3 年 (1237) 12 月 1 日の条。

6）注 5 の仁治 2 年 (1241) 4 月 12 日, 13 日の条。

7) 注 4 の弘安 10 年 (1287) 10 月 15 日の条。

8) 注 1 , 同年 4 月 27 日の条。

9）注 1 , 文永 12 年 (1275) 5 月 5 日の条。

10）『春日神社記録』神宮寺造替之記。

11）剚長 17 年 (1612) 正遷宮用調度注進状『春日神社文書第 壱』No. 339

12）『応永十四年下遷宮以後古物支配記』『貞治元年春日社正 遷宮記』同年 12 月 25 日の条。

13）『中臣祐重記』元暦 2 年 (1185) 12 月 11 日の条。

14）『中臣祐明記』建久 8 年 (1197) 3 月 8 日の条。

15）注 1 ，文永 4 年 (1267) 6 月 24 日の条, 建治元年 (1275) 8 月 23 日の条。

\section{5. 回廊, 南門の機能}

1. 回廊の機能

回嫏は複廊形式で，外部は 1 棟であるが，内部は 2 棟 の化粧軒裏となる。床は石敷きで，中央柱筋を連子密と し, 両側を開放とする。南回廊の南門東西に各一口, 東 回廊中央に一口，北回廊に一口の扉口を設けている。南 回廊東方の屝口は桜門，同西方の扉口は梅門，東回廊の 屝口は影向門, 北回廊の扉口は藤浪門と現在呼ばれる。 ただし，当社の回廊は春日祭の時に神事芸能などが行な われる庭や本殿, 三御廊，幣殿，直会殿，移殿，宝庫な どの一郭を囲んで建っては扔らず，東側北方招よび北側 東方では回廊を作らず，築垣を作っている。東北隅の筑 垣部分の地形は回廊床面よりがなり高く，また，春日宮 曼茶羅などをみても筑垣になっているので, 社地の東北 隅には始めから回廊はなかったものと推定される。

回廊の形式は他の神社に比べるとかなり立派で，桁行 全長 (外側側柱真々) $200.19 \mathrm{~m}$, 梁間（柱真々） 4.876 
$\mathrm{m}$, 総面積（柱真々） $976.927 \mathrm{~m}^{2}$ 亡規模も大である。し かし, 機能としては他の神社の回廊ほど重要な機能を持 っていないことをつぎに述べよう。

当社に扮ける神事で最も大切な春日祭の㭙に, 回廊は 使われることがない。祭り, 神事, 芸能などが行なわれ る時には他の多くの神社の場合では, 回廊は見物席にな ったり，㐫るいは実際に舞殿的性格を示す。例えば，鶴 岡八幡宮で行なわれたかの有名な静御前の舞などは下の 回廊で行なわれ，かつ将軍はじめ御家人達はこの回廊で 見物したのである。当社の回廊が春日祭の時に使用され ないことは注目すべきことであろう。

このことについて, 私はつぎのように考えたい。

当社の回廊は治承 3 年 (1179) に瑞垣を改內て創建さ れ，しかもこれより前に本殿前の三御廊が作られてい る。よって，春日祭やその他の神事秝よび仏事に特別必 要だから創建されたわけではなく，藤原氏の権勢を誇示 するために作られたものではなからうか。治承 3 年 (1179) と音光ば, 政治的には院政期に入って, 約 1 世 紀経ち安定していただろうし, 大きな戦乱もなく, 落着 いた時期だった。また，回廊は興福寺衆徒の強い要望に よって創建されたことも見逃せない事実である”。しか も, 回廊は以前の瑞垣の位置を踏襲して作られている。 春日祭やその他の神事の時には, 回廊創建以前に作られ た三御廊, 幣殿, 直会殿などを利用するので, 回廊が使 われなくても不思議ではない。だから，当社の回廊は複 廊で, 立派なものではあるが，機能は極言すれば瑞垣程 度のものと考えるのである。

また，当社境内では兵伏禁制になっているが，武具带 刀が許されるのは回廊に入る(外院)までで, 回廊内 （中院挍よび内院）では武具帯刀が許されなかったこと む加えておきたい22。

しかし，回廊が創建されてしまうと，後になって春日 祭以外に使われているので, つぎに述べよう。

境内の西のはずれに椇社水谷社が鎮座する。水谷社の ために毎年 4 月に神楽が举行される。それは現在でも 4 月 5 日行なわ和る水谷鎮花祭として有名である。この 時の神楽は本殿前, 三御廊の南, 幣殿の北側の庭で行な われ，淮備などに着到殿が利用される。ところが，当日 雨天の場合には庭で行ならわけにいかないので, 舞殿が 利用される。また，本殿の造替にぶつかり，着到殿に材 料が格納されていたり，着到殿の修理などにぶつかって 着到殿を利用することができない場合，などには回廊が やむなく利用されるのである ${ }^{3)}$ 。

しかし, 水谷社の神楽の当日, 雨天だったり, 着到殿 が使用不可能な状態だったことは極くまれなことで, 通 常は回瑯を利用することもなかった。回廊が水谷社の神 楽の時やむを得ず使われたとしても，恐らく見物の場所 として利用されたものと思う。

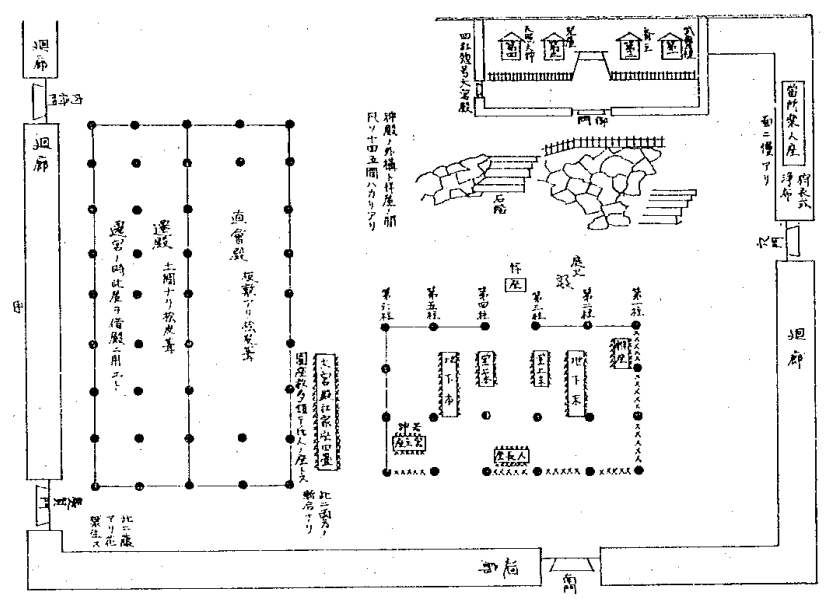

图一26『春日社七箇夜御神楽之記』(書) 天和 2 年 (1682) 11 月 28 日の条より転写

さて, 春日社には七ケ夜神楽といって, 神木が枯れた 時などに行なわれる神事がある。普通の神楽は保安 3 年 (1122）3月14日に行なおれたのが初めての上うだが, 七ケ夜神楽は『宣糺卿記』永正 4 年 (1506) 3 月 11 日に 行なわれたのが管見では最古のものであった。七ケ夜神 楽は神木 (春日山の山木) が枯れた時に行なわれるの で，それほど度々行なわれるものではなかったらしい。 江戸時代の記録であるが，天保 7 年 (1836) の『七ケ夜 御神楽記』に「於東廻廊奏楽先乱声」と記すので, 東回 廊がこの時使われだ)。ただし，東回廊といっても東回 廊全体を使うのではなく，影向門（図一26では「穴門」 と記す）の北を使用している。それを示すのが図一26 である。

その他，回廊が三方神人の集会に利用されたことがあ $る^{5)}$ 。三方神人は中臣氏を中心とする正預方の南郷の神 人と，大中臣氏を中心とする神主方の北郷の神人と，若 宮社の神人であろう。

また，本殿造替にさき立って，移殿に設けられる仮殿 の準備をするが, その準備は着到殿や回廊で行なわれ だ。。しか, 回廊が創建される前は, この準備も着到 殿のみで行なわれていたのであろう。

そして, 釿始の式の時に, 参詣人の腰掛に使う材木 (尼䝮)を東回廊内に置いて预いたこともある7。

また，江戸時代の記録ではあるが，遷宮の御视いに舞 楽を庭で行なった時,一乗院御門跡が御廊で見物し, 東 回廊で休息したと記すので, 東回廊は休息所として利用 されることもあっだ。

最後に, 回廊の機能として注目す心゙きこととして, 神 宮寺の造替の時に, 神宮寺の仮殿を東回廊に設けたこと を指滴しておく”。

神宮寺は『中臣祐重記』文治 2 年 (1186) 9 月 6 日の 条に初見されるが，その創建は四社殿創建以前とも伝え られわからない。しかし, 神宮寺は明治維新の神仏分離 令によって取り壞されたが, 古くから東御廊の南, 東回 廊の北のはずれの西にあったらしい。神宮寺を造替する 
時に，常に本殿造替の時と同じように仮殿もしくは仮殿 設備を設けていたかどらかわからないが，少なくとも回 廊が創建されてからは東回郎に度々設けられたのである 亏。

ここで, 神宮寺の造替の時に本殿造替時と同じように 仮殿設備を設けること，しかもそれが回廊内であること は注目される。ほかの神社の神宮寺の造替について, こ こでは明言できないが，仮殿設備を回廊内に設けるのは めずらしいことだと推測される。そして，仮殿設備が東 回廊内に設けられたのは神宮寺の位置加らであろう。ま た, 回廊が興福寺衆徒の強い要望のもとに創建されたこ とも想起される。今後, 神宮寺の造替について他の神社 の場合と比較しながら検証したい。

\section{口.南門の機能}

南門は当社で現在一番大きな門で，二層の楼.門であ る。このような形式になったのは回廊が創建された治承 3 年 (1179) でそれ以前は四足門であった。古くは鳥居 で, 承保 2 年 (1075) に四足閂に政造されたのである。

南門は当社に扔ける最も重要な神事である春日祭，西 るいは藤原氏以外の参詣などの場合に, 入口として使わ れながた。春日祭の時, 回廊内一の参入は『貞钼儀 式』によれば, 西方北の門（内侍門）であり，ずっと後 には慶賀門が使われた。そして，若宮社に参抨する時に は南門から出て若宮社入向ったのである。

しかし，若宮社創建以前の春日祭の時に南門から退出 したかどらかは資料で確認できなかった。

南門加らるるのは藤原氏関倸者の参洋の 時である。 『中臣祐賢記』弘安 2年 (1279) 1 月 25 日の条に「同夜, 祐冬元服, 同初参」として

戌剋, 神宮預神遅事 (中略) 入南阴参社, 賞家, と記す。ちなみに，上記は神宮預の参扯について記した ものである。この時の神宮預は同記 1月 24:日の条から， 明らか伦中臣祐親である。中臣氏は代々春日社の祠宮の 一人執行正預を勤めた家柄で, 若宮社が創建されてから は若宮社神主をも勤めた。祐親の息子が上記にみえる祐 冬で ${ }^{10)}$, この時元服し, 初参りをしたのであるから,こ わ時から氏人になったのである。当時, 元服し, 叙爵せ られて氏人になるのが普通である。また，上記に「当家 例边」と記すので, 中臣家の参抨の時には常に南門から 入っていたものと考えられ, 南門の性格を知る上で重要 であろう。

その他, 春白行宰の行事をするために, 上卿以下弁, その他の使い人達が参詣した時にも, 南門から入ってい

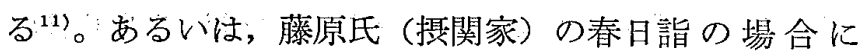
も, 南門加ら入って参垀している ${ }^{12)}$ 。『中右記』嘉承宇 年 (1106) 12 月,16日の条に

天晴, 殿下御春日詣也……承保二年例……入御彷菂

門, 永( 例丞,
と記すのは注目される。この時の氏の長者（殿下）は右 大臣藤原忠実であった。承保 2 年 (1075) といえば，南 門が鳥居から四足門に改造された時である。

さて, 平安時代の四足門について『海人藻芥』に「大 臣以上ならでは，此の門造らず」と記し，『枕草子』六 段には，大進生昌が家に，一条天皇の中宮藤原定子の御 方が行篮した際，このために東の門を四足門に造りかえ て乘興を迎えたことが書かれている。したがって，藤原 期においては四足門は高位の門制であった。

春日の南門を鳥居から四足門に改めたのも, 当社が藤 原氏の氏神であること, 当時政治の寒権を掌中におさめ た藤原氏の参詣と天皇の行幸の時に南門から入って参抨 したことなどの要因が考えられよう。ちなみに, 春日祭 の時に入口として使われる慶賀門やその他の門（内侍 門, 僧正門) は承保 2 年 (1075) には四足門に改造され ず鳥居のままであった。慶賀門, 内侍門, 僧正門が四足 門に改造されたのは治承 3 年 (1179) であろう。

内侍門はさきにもふれたように貞観時代, 春日祭の時 に参詣する内侍達の入口に使われたので,「内侍門」と 古くから称していたらしい。しかし, 僧正門および東回 廊にある影向門などの使われ方は資料不足のためはっき りつかめなかった。だが，影向門なども回廊の創建時か ら設けられたものと考えられ, その位置から多分に三笠 山を意識したものと推測されるので，今後検討したい。

なお，『中臣祐賢記』文永 2 年 (1265) 12 月 7 日の条 飞御参宮, ……御前ヨ過テ東廻廊内 $习$ 廻テ, 南門/東八 小 門ヨリ出テ, 若宮へ参シテ申祝了。

とみえるので，本社から若宮社八参抨する時に必ずしも 南門から出ていくとは限らなかったらしい。上記に「南 門ノ東ノ小門」と記すのは現在ある梅門のことであろ 亏。

回廊，南門における管見に当たった（幕末までの資 料）使われ方はおよそ以上であって，他に利用されてい ない。つぎに, 回廊, 南門の使われ方を要約しておく。

1）春日祭に使われない。瑞垣的性格をむつ。

2) 水谷社の祭りの時, 雨天で神楽など出来ない場合 に舞殿と共に臨時的に回廊が使われる。

3）神人達の集会を開いたこともある。

4）本殿造替の時, 仮殿の準備に着到殿と共に使われ た。

5）参扯者の一時的休息所として使われた。

6）東回廊，北の隅が常時倉庫として使われている。

7）神宮寺造替の時，仮殿を東回廊に設けた。

8）春日祭の時, 慶賀門から入り, 南門加ら出る。本 社に参张して, 若宮社へ行く時も南門は出口とな る。

9）藤原氏の氏の長者の参拝，天皇の行幸の時に限 り, 南門が出入口に使わ扎る。た, 正預, 若宮神 
主を勤める中臣氏の参挥も南門が使われる。

\section{[注]}

1）拙稿：中世春日社付属殿舎の造替について（2）(日本建 築学会論文報告集 第 223 号)。

2)『中臣祐賢記』文永 9 年 (1272) 8月 16 日の条。

3）『春日社司祐䊈記』永正 5 年 (1508) 4 月 2, 3 日の条には 「西ノ迴廊」が使われたと記すが，『春日社司祐稃記』は 「東ノ廻廊」と記す。

4）『公卿補任仁考』。

5）『春日社司祐維記』永正 15 年 (1518) 3 月 21 日の祭。

6）『春日社造替記』元応 2 年 (1320) 3 月 5 日の条。

7) 注 6 , 弘安 9 年 (1286) 12 月晦日の条。

8）『春日社御造営之記』元禄 2 年 (1689) 5 月 19 日の条。

9）『春日神社記録』神宮寺造替之記。

10）『春日社記録日記三』解説。

11）『中右記』永長 2 年 (1097) 3 月 27 日の条。

12) 注 11, 嘉承元年 (1106) 12 月 16 日の条。

結語 : 春日社本殿関係の各々の付属殿舎の機能につい ては各節每に要約したのでここではこれらの棈成， 利用を通じて，春日社全体において特に注目される諸点 をあげると，つぎのようである。

当社の神事，仏事の行事は幣殿，中門，若宮社拝舎の 床が土閒にもかかわらず，総て円座を用いて着座の姿勢 をとって行なわれた。神事で最も重要な春日祭は，中門 南, 幣殿北側の斎庭を中心にして行なわれる 庭儀であ る。そのために, 斎庭を取り囲む東・西御廊, 移殿, 直 会殿, 幣殿は石清水八幡宮, 鶴岡入幡宮などにお括ける回 廊的機能を有す。したがって，治承 3 年 (1179) に創建 された回廊は春日祭には使用されず，他の神社における 回廊とは性格を異にすると言えよう。

剤庭に着目して, 治承 3 年（1179）以前の春日社付属 殿舍の配置をみると, 斎庭の北側に東・西御廊, 南側に 幣殿 (舞殿)，西側に移殿，直会殿があって，東側に殿 舎はなかったらしい。東側にははるかにそびえる三笠山 があった。三笠山は『類聚三代格』承和 8 年 (841) 3 月

1 日の太政管符に

春日神山四至灼然。而今聞狩殍之輩触二穢斎場 $\ldots$ 。採樵

之人伐二損樹木一。神明仮し然恐及二國家一。

とみえるように，「神山」であると同時に「斎場」でも あった。そして, 斎庭は天平勝宝 8 年 (756) の東大寺网 から，三笠山の西にみえる「神池」の部分で，三笠山西 麓の祭場であったらしい。したがって，斉庭を取り用さ ようにして建てられた殿舎も三笠山のある東側には建て られなかったものと推測される。

このことは，春日祭の時に，参詣人達が三笠山に刘し て側面に当たる（南側）南門から大らず，正面に当たる (西側) 慶賀門加ら入こと，直会殿の着座の方法をみ ると氏人が西側に並び東面（三笠山に正詨）すること （後に藤原氏が衰えてから春日祭の参詣人が減った時に
は氏人に限らず東面した)，治承 3 年 (1178) に創建され た東回廊に「影向門」と称する小門をわざわざもらけた こと，などからも推察されよう。

そして，ずっと後になって創建された東・西御廊はさ ておいて，平安時代の春日祭の時に内侍達の着座の場所 となった移殿や神との直会を目的とする直会殿が㾮庭の 西側，才なわち三笠山を正面とし，並列して創建された ことも当然であると言えよう。

移殿や直会殿の西側には，回廊創建以前加慶賀門， 僧正門，内侍門の前身の鳥居があって，慶賀門の西側に は藤鳥居, さらに西には笼戸社が祭られていた。春日祭 の時には，上卿以下参詣人達はまず袚戸社前で袚戸の儀 を済ませ，藤鳥居，慶賀門を通って，まっすぐ三笠山に 向って進むのである。

袚户の儀に括ける着座の方法をみると, 袚戸社が南面 するにもかかわらず官位を有する人々が東面することな ぞも，春日社本殿よりも三笠山が重要視されているよう に思われる。

当社に打ける仏事は平安期に直会殿（八講屋）で行な われた法華八講が最初であろらが，その後間もなく創建 された三御廊で仏事が行なわれ，後の史料だが東御衩を 一切経廊, 西御廊を唯識論廊, 北御廊を定講廊と称する ことは注目される。つまり，創建年代の不明な神宮寺を 除けば，当社における仏教的行事は平安期にはじめられ たのである。そのために，三御廊の創建につながったの かも知れない。

なお，当社が藤原氏の氏神であることは言うまでもな い。氏の長者の参詣には常に南門が出入口に使われたこ と，平安期に高位の人の所にしか建てられない四足門に 鳥居から改造したこと，氏人だけが着到殿で休息するこ とができたこと，直会殿で氏人が東面して着座するこ と，などをみるとより一層氏神の感を強くする。

以上，春日社付属殿舎の機能を明らかにし，お上そそ の性格を知ることができ，神事，仏事，造替などの使い 方のらち，神事に使われるのが本来の使われ方であり， 神事のらち最も重要な春日祭の時に舞などに使われる斎 庭を中心に䌘殿 (舞殿)，直会殿，移殿 (内侍所）が建 てられ，しかもその配置は東にそびえる三笠山（神山） と決して無関係ではないことを明らかにすることができ た。今後, 他の神社の付属殿舎の穖能を調べ, これと比 較することによって，なお一層神社に押ける付属殿舎の 性格が見らかになるだろら。そして, 将来は寺院の付属 殿舎の性格と比較することによって, 神社建築の付属殿 舎の性格を明確にしたい。 
U.D.C. $726.139 .52(\mathrm{~K})$

ON THE FUNCTION OF BUILDINGS OTHER THAN FOUR MAIN SHRINES AND THE SMALLER ONES AT THE KASUGAA SHRINE (No. 2)

by MASAHIKO SATO, Assistant of Meiji Univ., Member of A.I.J.

This paper continues from No. I . [See No. 228 Feb. 1975 Trans. of A.I.J.]

U.D.C. $72.03: 72.071 .1(W)$

LIFE AND WORK OF ENGINEER-ARCHITECT THOMAS JAMES WATERS IN LATA YEDO AND EARLY MEIJI ERA

(Part 3 - On the so called agreement between Japanese Government and T.J. Waters and his post in the Mint)

by Dr. JURO KIKUCHI, Museum Meiji-Mura, Member of A.I.J.

Succeeding to the part 2 of this study, author consider a so-called agreement between Japanese Goverment and T.J. Waters from many angles, and conclude his connection to the Mint as chief engineer dating from the first day of November eighteen hundred and sixtyeight. 